\title{
Non Alcoholic Fatty Liver Disease: Assessment of Lipid Profile Estimation in Different Grades of Fatty Liver on Ultrasound
}

\author{
Bhojo Mal Tanwani' ${ }^{1}$ Anwar Ali Jamali ${ }^{*}$, Ghulam Mustafa Jamali ${ }^{2}$, Ameer Ali Jamali ${ }^{3}$, \\ Muhammad Ali Sohail ${ }^{4}$ \\ ${ }^{1}$ Department of Physiology, Peoples University of Medical and Health Sciences for Women, Nawabshah, Pakistan \\ ${ }^{2}$ Department of Medicine, Peoples University of Medical and Health Sciences, Nawabshah, Pakistan \\ ${ }^{3}$ Department of Pediatrics Medicine, Peoples University of Medical and Health Sciences for Women, Nawabshah, Pakistan \\ ${ }^{4}$ Department of Urology, Peoples University of Medical and Health Sciences for Women, Nawabshah, Pakistan \\ Email: ^jamalianwarali@gmail.com
}

How to cite this paper: Tanwani, B.M., Jamali, A.A., Jamali, G.M., Jamali, A.A. and Sohail, M.A. (2018) Non Alcoholic Fatty Liver Disease: Assessment of Lipid Profile Estimation in Different Grades of Fatty Liver on Ultrasound. Open Journal of Preventive Medicine, 8, 70-83.

https://doi.org/10.4236/ojpm.2018.83007

Received: February 14, 2018

Accepted: March 23, 2018

Published: March 26, 2018

Copyright $\odot 2018$ by authors and Scientific Research Publishing Inc. This work is licensed under the Creative Commons Attribution International License (CC BY 4.0).

http://creativecommons.org/licenses/by/4.0/

\begin{abstract}
Background: Non Alcoholic Fatty Liver Disease (NAFLD) is common hepatic disorder which is recognized as a great health problem causing different diseases worldwide. To determine non-alcoholic fatty liver and assess the relation of fasting total lipids with different grades of fatty liver (NAFLD) subjects diagnosed through ultrasound. By identifying the risk factors of Lipid Profile and NAFLD, the health care provider can properly manage it, even awareness specific for patients and community as general being launched to diminish the morbidity and mortality by this study. Methods: This cross-sectional research carried out at Medicine Department of PMCH, Shaheed Benazirabad. This study comprises 300 subjects of NAFLD. Patients who attended the medicine department with abdominal complains after examination consultant advised ultrasound. The ultrasound performed in Radiology department, patients with findings of fatty liver selected, and history taken from all the patients with special regard to alcoholism. Fasting lipid profile done in all patients included in present study. The blood samples collected from a vein and immediately sent to the laboratory. Results: This present study enlisted total 300 patients out of them 203 (67.7\%) belonged to male gender and 97 (32.3\%) were females. A ratio of 2.1:1 observed in male and female subjects. There were 176 (58.7\%) patients in grade I, while $82(27.3 \%)$ patients in grade II and $42(14 \%)$ patients in grade III. The cholesterol value was abnormal in $186(62 \%)$, while normal in remaining $114(38 \%)$ patients. Triglycerides were abnormal in 152 (50.7\%) while in 148 (49.3\%) patients were normal. HDL in 155 (51.7\%) patients was abnormal while 145 (48.3\%) patients had normal values. Low den-
\end{abstract}


sity lipoprotein value in 117 (39\%) patient was abnormal and $183(61 \%)$ patient normal. Very low-density lipoprotein in 117 (39\%) patients was abnormal and 183 (61\%) patient normal. The mean age and SD of patients in present study was $46.83 \pm 8.82$, with minimum 30 years and maximum age 65 years respectively ( $\mathrm{p}$ value 0.000 ). The mean and SD of total cholesterol value was $154.66 \pm 58.88 \mathrm{mg} / \mathrm{dl}$ (p value 1.000), TG $180.98 \pm 96.46 \mathrm{mg} / \mathrm{dl}$ ( $\mathrm{p}$ value 0.974 ), HDL-C $32.13 \pm 5.88 \mathrm{mg} / \mathrm{dl}$ (p value 0.000$)$, LDL-C $116.41 \pm 41.002$ $\mathrm{mg} / \mathrm{dl}$ ( $\mathrm{p}$ value 0.000 ), and VLDL-C was $43.47 \pm 34.34 \mathrm{mg} / \mathrm{dl}$ ( $\mathrm{p}$ value 0.000 ). Conclusions: In current study, variable changes in lipid profile observed amongst NAFLD (non-alcoholic fatty liver disease) patients who diagnosed on ultrasound. Early diagnosis and treatment of non alcoholic fatty liver with abnormal lipids can prevent from long-term complication of fatty liver.

\section{Keywords}

Lipid Profile, NAFLD (Nonalcoholic Fatty Liver Disease), Ultrasound, Grades of Fatty Liver

\section{Introduction}

In non-alcoholic population, excessive and abnormal fat deposition in the liver cells is identified as NAFLD. NAFLD had been identified as a common frequent etiologic factor of hepatic ailment [1]. Nonalcoholic fatty liver disease first described almost 60 years ago, although Jurgen Ludwig a pathologist finally recognized it in 1980. In patients with steatohepatitis without noteworthy or with minimal alcohol utilization, histo-pathological findings were described by him. His observations were valid and he described that in majority of subjects there were marked inflammation of liver with necrotic areas. Fatty liver (non-alcoholic disease) is deposition of fats in hepatocytes (steatosis) and is either simple steatosis or steatohepatitis. When there is fatty change due to deposition of abnormal lipids in the hepatic cells, it leads to steatohepatitis simply or steatosis associated with hepatic fibrotic or cirrhotic change called steatohepatitis [2].

In western population, fatty liver disease (non-alcoholic) is widespread etiologic agent for chronic hepatic disease (CLD) [3]. However, it is now growing in the Asia-Pacific location especially due to change in life style as increased use of fat, lack of exercise, and rising burden of the DM-2 [4].

On the basis of histological characters, NAFLD (Non-alcoholic fatty liver disease) is classified in grade I, II, and III. In grade I (simple steatosis), liver echogenicity is raised and the periportal and diaphragmatic echogenicity is visualized on ultrasonography. In grade II, there is alteration in the echo pattern of liver characterized by inflammation of lobules with steatosis and ballooning of liver cells. Ultrasonic characters in grade III are raised hepatic echogenicity along with imperceptible periportal echogenicity with obstruction of diaphragm (inflammation of lobules with steatosis and ballooning of liver cells and fibrosis of 
Mallory hyaline) [5]. It is simply from deposition of fat (steatosis) to fibrotic and or cirrhotic change (steatohepatitis). In simple steatosis, there is buildup of fats as TG inside hepatic cells, and in non-alcoholic steatohepatitis, there is deposition of lipid in the liver cells along with evidence of liver cell injury, fibrosis (various degrees) and inflammation [6].

NAFLD occurs with obesity approximately in $40 \%$, as well as $15 \%$ of overweight subjects. There is increased occurrence of non-alcoholic fatty liver disease (NAFLD) in relationship to T2DM. It is suggested that by 2020 size of populace with DM-2 will be touching to 100 million worldwide. Unpredictably $60 \%$ will be from Asia. NAFLD seems frequently asymptomatic without signs of hepatic ailment in subjects at diagnosis. NAFLD is exposed either on usual ultrasonography, or when performing investigations for other ailments such as Hypertension and DM with or without obesity [6] [7] [8]. Feeling of fullness and uneasiness in right upper abdomen, tiredness and malaise is reported in many subjects. Enlargement of liver is clinically observed in many patients [9]. It is more prone to develop in patients with diabetes mellitus; hypertension, obesity and male gender [10].

Occurrence of fatty liver disease (non-alcoholic) is $7 \%-9 \%$ in general populace throughout World; amazingly, 12\% - 24\% general Asian population is affected. $30 \%$, of United States general inhabitants have NAFLD and non-alcoholic fatty liver morbidly affects $90 \%$ of the obesity subjects [11].

To observe the incidence of risk factors a study done in Rawapindi, Pakistan, which shown obesity in 66\%, increased levels of triglycerides in $48 \%$, DM in $34 \%$ and increased levels of cholesterol in $28 \%$ of subjects [12]. A study performed at Institute of Pharmaceutical Sciences, Telangana, India observed various grading of NAFLD with ultrasonography and estimated fasting profile of lipid in patients. To analyze the abnormal lipid profile in NAFLD, subjects with various age levels were included in the research. Lipid profile alteration observed $12.72 \%$ in 30 - 39 years, $33.93 \%$ in 40 - 49 years, $20.61 \%$ in 50 - 59 years and $17.58 \%$ in 60 - 69 years respectively. Santoshini A et al. in their study concluded that the effect of age has great impact on lipid profile in different grades of NAFLD subjects which were statistically significant [13].

Biopsy of liver (LB) is an authentic final invasive test to diagnose and stage with numerous disadvantages, because of pain, cost, high rates of complications with agony and uneasiness. Ultrasonic findings along with considerably raised fasting lipid profile are the safe, cheap, easy, and accurate available diagnostic tool for fatty liver disease (non-alcoholic). Ultrasound (USG) considered as the foremost imaging technique for establishing and categorizing the fatty liver disease and is extensively used in suspects of fatty liver (non-alcoholic disease) also analyzing asymptomatic subjects with raised hepatic enzymes.

This cross-sectional research conducted for estimation of the fasting lipids in NAFLD grades assessed by Ultrasound [14] [15] [16].

Only a little number of studies reported on fatty liver (non-alcoholic disease) 
subjects from Pakistan established on ultrasound. This research compared lipid profile of subjects through various grading of NAFLD diagnosed ultrasonographically.

Present study was done to assess fasting lipids and their association with different NAFLD grades through Ultrasonography.

By early reorganization of abnormal fasting lipids and NAFLD will help in early protective management and prevention of complications due NAFLD through prompt specific measures to decrease the burden of disease and outcome in terms of disability and death.

\section{Methods}

\subsection{Ethical Considerations}

This study was performed after the permission of ethical committee Peoples Medical University Hospital Nawabshah Pakistan. All the subjects were provided written informed consent.

\subsection{Study Population}

This cross sectional research conducted in departments of Medicine Peoples Medical College Hospital Nawabshah (SBA), criteria of patients in this study male and female subjects with age from 30 years above and diagnosed NAFLD on ultrasonography. Sample size was 300 subjects. Online calculator of rao-software for sample size calculation was used, with margin of error 5.68\% and confidence level $91.7 \%$ population size of 1,600,000. Study conducted from March 2016 to February 2017. Particular proforma was designed for the data collection. History obtained in full from all subjects and particularly of alcohol consumption. Fasting lipid profile done in all patients under study. Blood samples were collected after strict antiseptic measures from a vein and immediately transported to the laboratory for lipid profile analysis. Blood samples were centrifugated and serum was drawn for blood and analyzed through Micro-lab 300 Merck. Different grades of hepatic fat were assessed by ultrasound and its relation with lipid profile. In this research patients included with age range from 30 - 65 years with NAFLD (non-alcoholic fatty liver disease) on ultrasound. Exclusion criteria included subject's age less than 30 years and more than 70 years or above, denied to participate, with comorbidities of DM, viral hepatitis (Hepatic viruses B or C) and alcoholism. Accumulation/deposition of Fat in hepatic cells leading to fatty liver owing to reasons excluding alcohol abuse in patients is defined as NAFLD.

\subsection{Biochemical Examination}

A blood test that primarily used to detect the derangements of lipid by measuring the serum levels of TC and TG levels. Normal values of lipid profile are TC less than $200 \mathrm{mg} / \mathrm{dl}$, TG $46-236 \mathrm{mg} / \mathrm{dl}$, HDL $>35 \mathrm{mg} / \mathrm{dl}$, LDL $<130 \mathrm{mg} / \mathrm{dl}$ and levels of $\mathrm{VLDL}<30 \mathrm{mg} / \mathrm{dl}$ are considered normal [17]. 


\begin{tabular}{ccc}
\hline TEST & Cholesterol Level & Category \\
\hline \multirow{2}{*}{ CHOLESTROL } & Less than $200 \mathrm{mg} / \mathrm{dl}$ & Desirable \\
& $200-239 \mathrm{mg} / \mathrm{dl}$ & Borderline high \\
$240 \mathrm{mg} / \mathrm{dL}$ and above & High \\
TRIGLYCERIDES & $<150 \mathrm{mg} / \mathrm{dl}$ & Normal \\
& $150-199 \mathrm{mg} / \mathrm{dl}$ & Borderline high \\
& $200 \mathrm{mg} / \mathrm{dL}-499 \mathrm{mg} / \mathrm{dl}$ & High \\
H.D.L & $\geq 500$ & Very High \\
& More Than Or Equal To 40 & Optimal \\
& $<\mathrm{Mg} / \mathrm{Dl}$ & Optimal Level \\
L.D.L & $<100 \mathrm{mg} / \mathrm{dl}$ & Above Optimal Level \\
& $100-129 \mathrm{mg} / \mathrm{dl}$ & Borderline High Level \\
& $130-159 \mathrm{mg} / \mathrm{dl}$ & High Level \\
V.L.D.L & $\geq 190 \mathrm{mg} / \mathrm{dl}$ & Very High Level \\
& $<30 \mathrm{mg} / \mathrm{dl}$ & OPTIMAL \\
\hline
\end{tabular}

NCEP ATP III Guidelines.

\subsection{Ultrasound Examination}

Valid guidelines as per recommendations of association of American gastroenterologist were followed to diagnose fatty liver according to severity as mild grade I, moderate as grade II and severe as Grade III. In Grade I there is little widespread increase in fine echoes on ultrasound. Hepatic appearance is light in contrast to renal cortex. In Grade II there is moderately diffusing fine echoes on ultrasound. Grade III there is distinct raise in fine echoes on Ultrasound [2].

\subsection{Statistical Analysis}

Data collected was analyzed through SPSS version 20.0. Different variables like TC, TG, HDL, LDL and VLDL were assessed to check percentages and frequencies with different grades of fatty liver. Categorical variables were assessed for mean \& SD, like age sex and others. Effect modifiers; age, gender, lipid profile all controlled by stratification. Variables were analyzed by chi-square test.

\section{Results}

This present study enlisted total 300 patients out of them 203 (67.7\%) belonged to male gender and 97 (32.3\%) were females, 280 (93.9\%) married and 20 (6.7\%) were unmarried.

Education profile show that 80 (26.7\%) illiterate, 107 (35.7\%) primary level, 30 (10\%) middle level, 30 (10\%) matriculation level, 34 (11.3\%) intermediate level while only 17 (5.7\%) were graduated. A waste number of patients 274 (91.3\%) belonged to lower economic class, while 17 (5.7\%) to middle class and 09 (3.0\%) to upper class.

Regarding occupation of patients, 29 (9.7\%) no occupation, 63 (21\%) housewife, while major portion of patients 190 (63.3\%) were manual workers and remaining 18 (6\%) were office workers. Most of the patients belonged to the rural 
community $231(77 \%)$ and 69 (23\%) were living in urban areas (Figure 1).

Body mass index BMI was normal in 177 (59\%), 112 (37.3\%) overweight \& 11 (3.7\%) patients were obese. There were 176 (58.7\%) patients in grade I, while 82 $(27.3 \%)$ patients in grade II and $42(14 \%)$ patients in grade III.

The cholesterol value was abnormal in 186 (62\%), while normal in remaining 114 (38\%) patients. Triglycerides were abnormal in 152 (50.7\%) while in 148 (49.3\%) patients was normal. HDL in 155 (51.7\%) patients was abnormal while $145(48.3 \%)$ patients had normal values. Low density lipoprotein value in 117 (39\%) patient was abnormal and 183 (61\%) patient normal. Very low-density lipoprotein in 117 (39\%) patients was abnormal and 183 (61\%) patient normal (Figure 2).

The mean age and SD of patients in present study was $46.83 \pm 8.82$, with minimum 30 years and maximum age 65 years respectively ( $\mathrm{p}$ value 0.000 ). The mean and SD of total cholesterol value was $154.66 \pm 58.88 \mathrm{mg} / \mathrm{dl}$ (p value 1.000 ), TG $180.98 \pm 96.46 \mathrm{mg} / \mathrm{dl}$ (p value 0.974), HDL-C $32.13 \pm 5.88 \mathrm{mg} / \mathrm{dl}(\mathrm{p}$ value 0.000 ), LDL-C $116.41 \pm 41.002 \mathrm{mg} / \mathrm{dl}$ ( $\mathrm{p}$ value 0.000 ), and VLDL-C was $43.47 \pm$ $34.34 \mathrm{mg} / \mathrm{dl}$ (p value 0.000 ) (Table 1 ).

In present study there was statistically significant correlation of triglycerides with grades of fatty liver ( $p$ value 0.012 ), age ( $p$ value 0.030 ), cholesterol ( $p$ value 0.000 ), LDL-C (p value 0.000 ) and VLDL-C (p value 0.000 ).

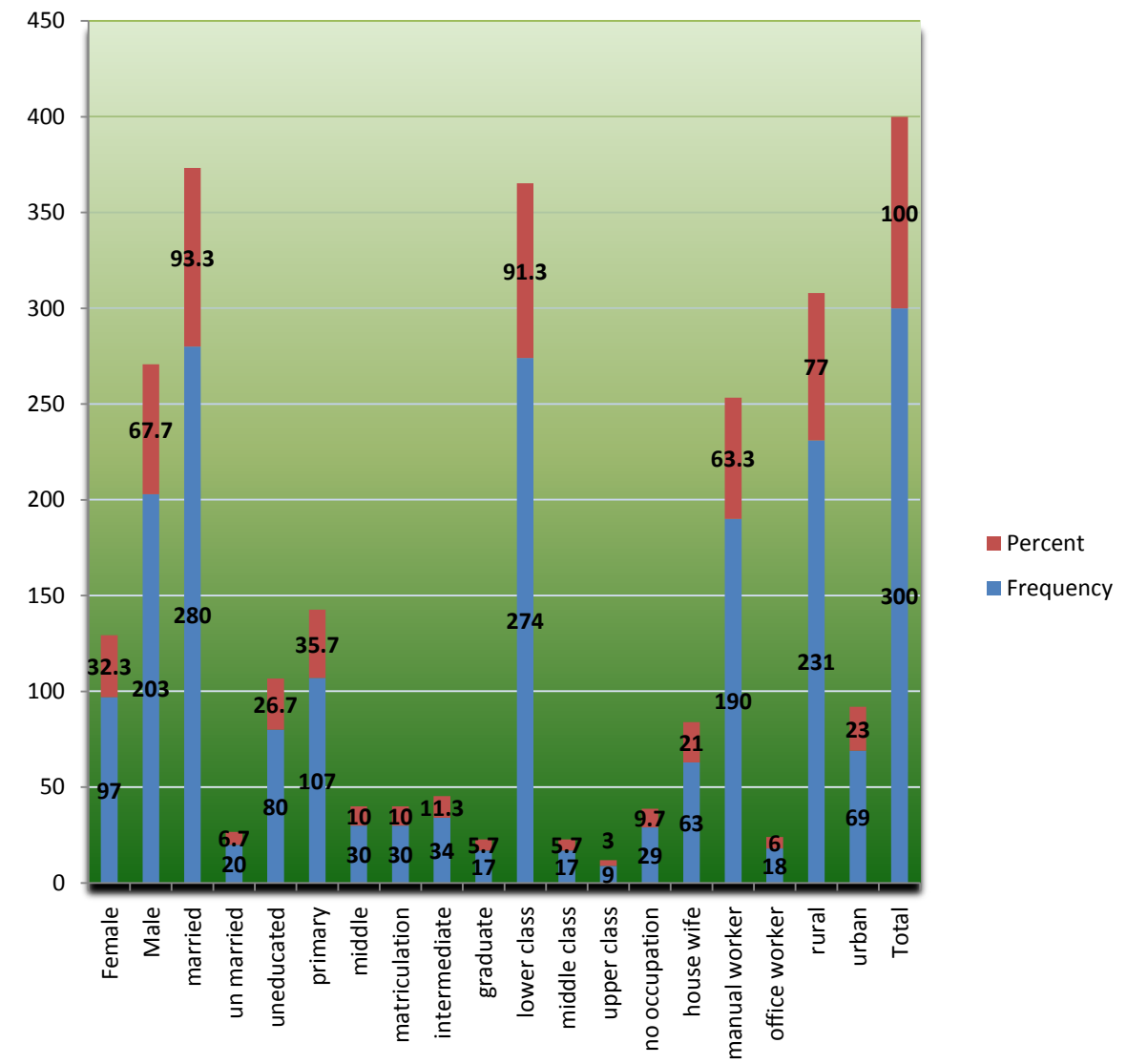

Figure 1. Frequency and percentages of demographic variables. $\mathrm{n}=300$. 


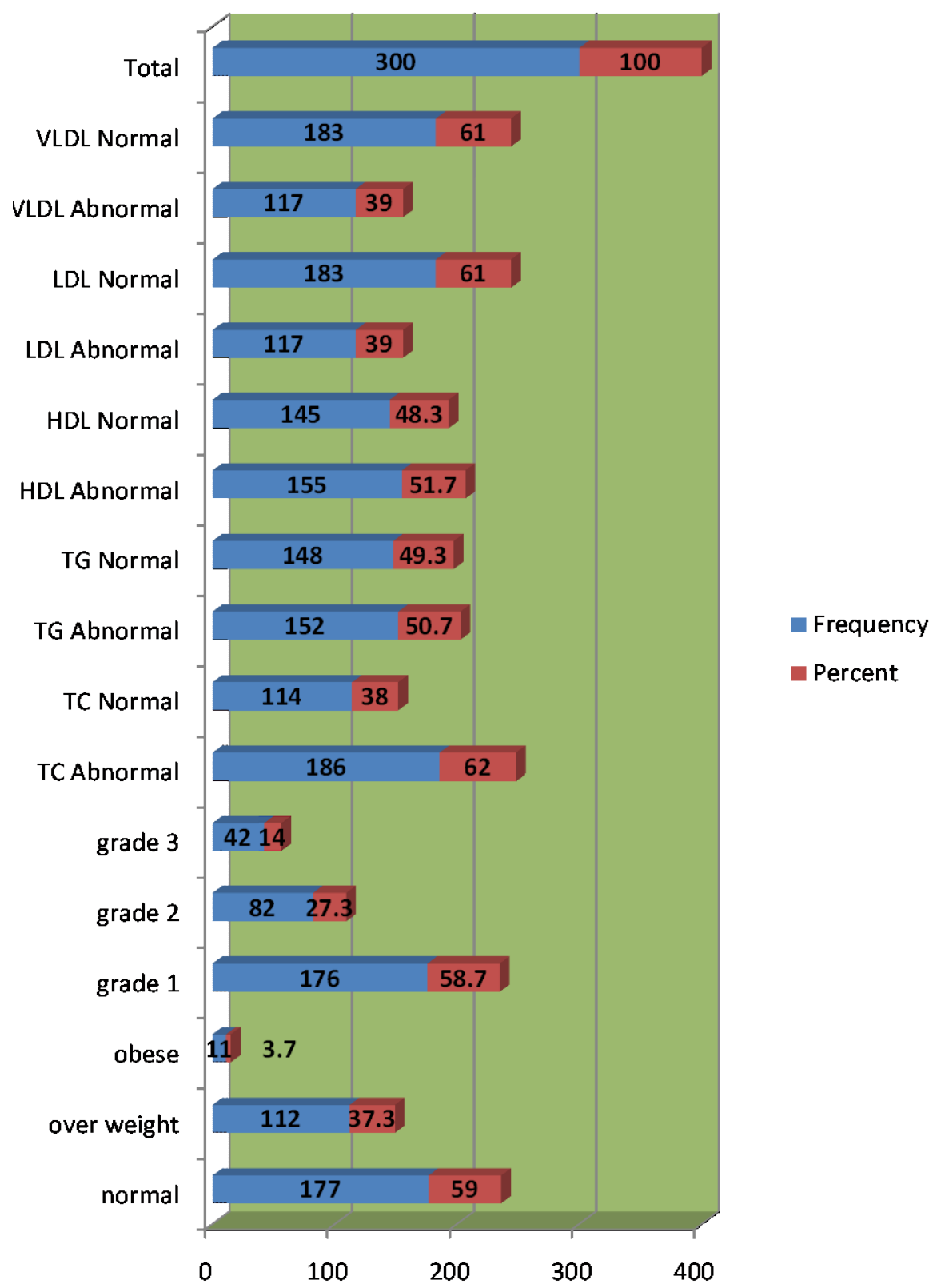

Figure 2. Frequency and percentages of lipid profile, grades of fatty liver and BMI. $n=$ 300.

The correlation of age was statistically significant with TG-C (p-value 0.030) and no significant relation with grading of fatty liver and rest of lipid profile.

The correlation of grades of fatty liver was statistically significant with TG-C (p-value 0.012 ) and no significant relation with age and other variables of lipid profile (Table 2).

The percentage of total cholesterol within different grades of fatty liver was normal in $114(38 \%)$ and abnormal $186(62 \%)$ of patients. In grade I there were $72(40.90 \%)$ normal and $104(59.140 \%)$ abnormal, in grade II there were 31 (37.80\%) normal and $51(62.20 \%)$ abnormal and in grade III $11(26.20 \%)$ normal, 31 (73.80\%) were abnormal ( $\mathrm{p}$ value 0.210 ). 
Table 1. Statistical values of age and lipid profile $n=300$.

\begin{tabular}{|c|c|c|c|c|c|c|}
\hline $\begin{array}{c}\text { Statistics } \\
\text { Statistivariable }\end{array}$ & $\begin{array}{c}\text { Age } \\
\text { In Years }\end{array}$ & $\begin{array}{c}\text { Cholesterol } \\
\text { Level mg/dl } \\
\text { Normal Less than } \\
200 \mathrm{mg} / \mathrm{dl}\end{array}$ & $\begin{array}{c}\text { Triglyceride } \\
\text { Level mg/dl } \\
\text { Normal }<150 \mathrm{mg} / \mathrm{dl}\end{array}$ & $\begin{array}{c}\text { High Density } \\
\text { Cholesterol Level } \\
\text { mg/dl } \\
\text { Normal }>40 \mathrm{mg} / \mathrm{dl}\end{array}$ & $\begin{array}{c}\text { Low Density } \\
\text { Lipoprotein } \\
\text { Level } \mathrm{mg} / \mathrm{dl} \\
\text { Normal< } 100 \mathrm{mg} / \mathrm{dl}\end{array}$ & $\begin{array}{c}\text { Very Low Density } \\
\text { Lipoprotein Level } \\
\mathrm{mg} / \mathrm{dl} \\
\text { Normal }<30 \mathrm{mg} / \mathrm{dl}\end{array}$ \\
\hline Mean & 46.8367 & 154.6679 & 180.9884 & 32.1379 & 116.4180 & 43.4762 \\
\hline Std. Error of Mean & 0.50937 & 3.39960 & 5.56970 & 0.33971 & 2.36727 & 1.98281 \\
\hline Median & 47.0000 & 147.9500 & 192.4500 & 30.9500 & 102.2250 & 29.0000 \\
\hline Mode & 49.00 & $95.23^{\mathrm{a}}$ & $28.50^{\mathrm{a}}$ & 36.00 & 100.20 & 28.50 \\
\hline Std. Deviation & 8.82248 & 58.88273 & 96.46998 & 5.88387 & 41.00236 & 34.34324 \\
\hline Variance & 77.836 & 3467.176 & 9306.457 & 34.620 & 1681.194 & 1179.458 \\
\hline Range & 35.00 & 188.98 & 306.22 & 36.15 & 193.02 & 173.13 \\
\hline Minimum & 30.00 & 77.25 & 26.90 & 22.00 & 5.23 & 11.12 \\
\hline Maximum & 65.00 & 266.23 & 333.12 & 58.15 & 198.25 & 184.25 \\
\hline p-value & 0.000 & 1.000 & 0.974 & 0.000 & 0.000 & 0.000 \\
\hline
\end{tabular}

a. Multiple modes exist. The smallest value is shown.

Table 2. Correlations of different grades of fatty liver and age with lipid profile $n=300$.

\begin{tabular}{|c|c|c|c|c|c|c|c|c|}
\hline & $\begin{array}{l}\text { Statistical } \\
\text { parameters }\end{array}$ & $\begin{array}{l}\text { Grades Of } \\
\text { Fatty Liver }\end{array}$ & $\begin{array}{l}\text { Age In } \\
\text { Years }\end{array}$ & $\begin{array}{c}\text { Cholesterol } \\
\text { Level }\end{array}$ & $\begin{array}{c}\text { Triglyceride } \\
\text { Level }\end{array}$ & $\begin{array}{c}\text { High Density } \\
\text { Cholesterol } \\
\text { Level }\end{array}$ & $\begin{array}{l}\text { Low Density } \\
\text { Lipoprotein } \\
\text { Level }\end{array}$ & $\begin{array}{c}\text { Very Low } \\
\text { Density } \\
\text { Lipoprotein } \\
\text { Level }\end{array}$ \\
\hline Grades Of Fatty & Pearson Correlation & 1 & 0.025 & 0.052 & $0.145^{\star}$ & 0.015 & 0.096 & 0.097 \\
\hline Liver & Sig. (2-tailed) & & 0.672 & 0.366 & 0.012 & 0.797 & 0.098 & 0.093 \\
\hline \multirow{2}{*}{ Age In Years } & Pearson Correlation & 0.025 & 1 & 0.086 & $0.125^{*}$ & -0.094 & 0.081 & 0.057 \\
\hline & Sig. (2-tailed) & 0.672 & & 0.139 & 0.030 & 0.103 & 0.161 & 0.326 \\
\hline Cholesterol & Pearson Correlation & 0.052 & 0.086 & 1 & $0.518^{\star *}$ & $-0.261^{\star *}$ & $0.639^{* *}$ & $0.544^{\star *}$ \\
\hline Level & Sig. (2-tailed) & 0.366 & 0.139 & & 0.000 & 0.000 & 0.000 & 0.000 \\
\hline Triglyceride & Pearson Correlation & $0.145^{\star}$ & $0.125^{\star}$ & $0.518^{\star *}$ & 1 & -0.025 & $0.685^{\star *}$ & $0.537^{\star *}$ \\
\hline Level & Sig. (2-tailed) & 0.012 & 0.030 & 0.000 & & 0.664 & 0.000 & 0.000 \\
\hline $\begin{array}{c}\text { High Density } \\
\text { Cholesterol }\end{array}$ & Pearson Correlation & 0.015 & -0.094 & $-0.261^{* *}$ & -0.025 & 1 & $-0.236^{* *}$ & $-0.362^{\star *}$ \\
\hline Level & Sig. (2-tailed) & 0.797 & 0.103 & 0.000 & 0.664 & & 0.000 & 0.000 \\
\hline $\begin{array}{l}\text { Low Density } \\
\text { Lipoprotein }\end{array}$ & Pearson Correlation & 0.096 & 0.081 & $0.639^{* *}$ & $0.685^{\star *}$ & $-0.236^{\star \star}$ & 1 & $0.676^{* *}$ \\
\hline Level & Sig. (2-tailed) & 0.098 & 0.161 & 0.000 & 0.000 & 0.000 & & 0.000 \\
\hline $\begin{array}{l}\text { Very Low } \\
\text { Density }\end{array}$ & Pearson Correlation & 0.097 & 0.057 & $0.544^{\star *}$ & $0.537^{\star *}$ & $-0.362^{\star \star}$ & $0.676^{\star *}$ & 1 \\
\hline $\begin{array}{l}\text { Lipoprotein } \\
\text { Level }\end{array}$ & Sig. (2-tailed) & 0.093 & 0.326 & 0.000 & 0.000 & 0.000 & 0.000 & \\
\hline
\end{tabular}

${ }^{*}$ Correlation is significant at the 0.05 level (2-tailed). ${ }^{*}$ Correlation is significant at the 0.01 level (2-tailed).

The percentage of TG within different grades of fatty liver was normal in 148 $(49.30 \%)$ and abnormal $152(50.70 \%)$ of patients. In grade I there were 90 (51.10\%) normal and $86(48.90 \%)$ abnormal, in grade II there were $36(43.90 \%)$ 
normal and 46 (56.10\%) abnormal. and in grade III 22 (52.40\%) normal, 20 (47.60\%) were abnormal ( $\mathrm{p}$ value 0.509 ).

The percentage of HDL-C within different grades of fatty liver was normal in $145(48.30 \%)$ and abnormal $155(51.70 \%)$ of patients. In grade I there were 82 (46.60\%) normal and 94 (53.40\%) abnormal, in grade II there were 41 (50\%) normal and 41 (50\%) abnormal and in grade III 22 (52.40\%) normal while 20 (47.60\%) were abnormal ( $\mathrm{p}$ value 0.748 ).

The percentage of LDL within different grades of fatty liver was normal in 183 (61\%) and abnormal 117 (39\%) of patients. In grade I there were $106(60.20 \%)$ normal and $70(39.80 \%)$ abnormal, in grade II there were 49 (59.80\%) normal and $33(40.20 \%)$ abnormal and in grade III 28 (66.70\%) normal, 14 (33.30\%) were abnormal ( $\mathrm{p}$ value 0.717 ).

The percentage of VLDL within different grades of fatty liver was normal in $183(61 \%)$ and abnormal $117(39 \%)$ of patients. In grade I there were 109 (61.90\%) normal and 67 (38.10\%) abnormal, in grade II there were 46 (56.10\%) normal and 36 (43.90\%) abnormal and in grade III 28 (66.70\%) normal while 14 (33.30\%) were abnormal (p-value 0.482) (Table 3).

\section{Discussion}

In present study we had demonstrated the lipid profile abnormalities with different grades of fatty liver. NAFLD is a global health issue. It is also very common in our setup also. Lot of factors is responsible in our setup. It needs urgent consideration for the better management. It may result in lot of complications if not controlled accordingly. Pakistan is a resource poor country, the prevalence of the different disease burden is very high, and here mortality and morbidity is increasing day by day. Low education profile, poverty, poor sanitation, lack of health education, lack of resources, gender dominance, urbanization, un-employment are the main hindrances in health management of common peoples.

Pathological findings of NAFLD in consequence with progression range deposition of cells in liver cell (steatosis) to cirrhosis and advanced fibrosis (steatohepatitis), these all-pathologic characteristics are also seen in alcoholic liver disease and in non-alcoholics. Steatohepatitis (non-alcoholic) usually considered as intermediate stage of fatty liver (non-alcoholic disease) and is described by the steatosis, injury to hepatic cells, and inflammation of liver, necrosis and fibrosis [18]. Male subjects who have obesity, hypertension and diabetes mellitus had more commonly NAFLD (Non-alcoholic fatty liver disease). Very few researches had conducted ultrasound studies in fatty liver (non-alcoholic disease) subjects. It is prevalent amongst male gender; most reported cases are normotensive, non-diabetic and have normal BMI [13]. In current study males are predominant as compared with females; 203 males $(67.7 \%)$ and 97 females $(32.3 \%)$ included; with male: female ratio of 2.1:1. In a study by Santoshini A et al., majority of participants 97 (58.79\%) males and females were 68 (41.21\%) [13]. 
Table 3. Cross tabulation of lipid profile with different grades of NAFLD. $\mathrm{n}=300$.

\begin{tabular}{|c|c|c|c|c|c|c|c|c|c|c|c|c|c|}
\hline \multirow{2}{*}{$\begin{array}{l}\text { Variable } \\
\text { with } \mathrm{P} \\
\text { values }\end{array}$} & \multirow{2}{*}{$\begin{array}{l}\text { Statistical } \\
\text { parameters }\end{array}$} & \multicolumn{3}{|c|}{ GRADE I } & \multicolumn{3}{|c|}{ GRADE II } & \multicolumn{3}{|c|}{ GRADE III } & \multirow{2}{*}{$\begin{array}{c}\text { Grade } \\
\text { I II III } \\
\text { Abnormal } \\
\text { Total } \\
\text { Abnormal }\end{array}$} & \multirow{2}{*}{$\begin{array}{c}\text { Grade } \\
\text { I II III } \\
\text { Normal } \\
\text { Total } \\
\text { Normal }\end{array}$} & \multirow{2}{*}{$\begin{array}{l}\text { Total \% } \\
\text { Total \% }\end{array}$} \\
\hline & & Abnormal & Normal & Total & Abnormal & Normal & Total & Abnormal & Normal & Total & & & \\
\hline & Count & 104 & 72 & 176 & 51 & 31 & 82 & 31 & 11 & 42 & 186 & 114 & 300 \\
\hline $\begin{array}{c}\text { TC } \\
\text { p } 0.210\end{array}$ & $\begin{array}{l}\text { \% Within } \\
\text { Grades Of } \\
\text { Fatty Liver }\end{array}$ & $59.10 \%$ & $40.90 \%$ & $100.00 \%$ & $62.20 \%$ & $37.80 \%$ & $100.00 \%$ & $73.80 \%$ & $26.20 \%$ & $100.00 \%$ & $62.00 \%$ & $38.00 \%$ & $100 \%$ \\
\hline & Count & 86 & 90 & 176 & 46 & 36 & 82 & 20 & 22 & 42 & 152 & 148 & 300 \\
\hline $\begin{array}{c}\text { TG } \\
\text { p } 0.509\end{array}$ & $\begin{array}{l}\text { \% Within } \\
\text { Grades Of } \\
\text { Fatty Liver }\end{array}$ & $48.90 \%$ & $51.10 \%$ & $100.00 \%$ & $56.10 \%$ & $43.90 \%$ & $100.00 \%$ & $47.60 \%$ & $52.40 \%$ & $100.00 \%$ & $50.70 \%$ & $49.30 \%$ & $100 \%$ \\
\hline $\begin{array}{c}\text { HDL } \\
\text { p } 0.748\end{array}$ & $\begin{array}{l}\text { \% Within } \\
\text { Grades Of } \\
\text { Fatty Liver }\end{array}$ & $53.40 \%$ & $46.60 \%$ & $100.00 \%$ & $50.00 \%$ & $50.00 \%$ & $100.00 \%$ & $47.60 \%$ & $52.40 \%$ & $100.00 \%$ & $51.70 \%$ & $48.30 \%$ & $100 \%$ \\
\hline & Count & 70 & 106 & 176 & 33 & 49 & 82 & 14 & 28 & 42 & 117 & 183 & 300 \\
\hline $\begin{array}{c}\text { LDL } \\
\text { p } 0.717\end{array}$ & $\begin{array}{l}\text { \% Within } \\
\text { Grades Of } \\
\text { Fatty Liver }\end{array}$ & $39.80 \%$ & $60.20 \%$ & $100.00 \%$ & $40.20 \%$ & $59.80 \%$ & $100.00 \%$ & $33.30 \%$ & $66.70 \%$ & $100.00 \%$ & $39.00 \%$ & $61.00 \%$ & $100 \%$ \\
\hline & Count & 67 & 109 & 176 & 36 & 46 & 82 & 14 & 28 & 42 & 117 & 183 & 300 \\
\hline $\begin{array}{c}\text { VLDL } \\
\text { p } 0.482\end{array}$ & $\begin{array}{l}\text { \% Within } \\
\text { Grades Of } \\
\text { Fatty Liver }\end{array}$ & $38.10 \%$ & $61.90 \%$ & $100.00 \%$ & $43.90 \%$ & $56.10 \%$ & $100.00 \%$ & $33.30 \%$ & $66.70 \%$ & $100.00 \%$ & $39.00 \%$ & $61.00 \%$ & $100 \%$ \\
\hline
\end{tabular}

Mean age and SD of study subjects were $46.83 \pm 8.82$ years. The peak age group with presentation of NAFLD in recent research was 40 to 65 years which is comparable to other study conducted by Roli Agarwal et al. [19] in which mean age of subjects were $42.90 \pm 10.54$ years and Amrapurkar et al. [20] had shown mean age as 55.4 years. In western communities, studies had shown mean age of subjects ranging from $41-45$ years. In this study it is observed that our subjects were 5 - 10 years elder than the subjects studied elsewhere, this is because NAFLD in our subjects is observed in $4^{\text {th }}$ and $5^{\text {th }}$ decades.

Difference of fat distribution in the body or antioxidant system possibly regarded as the genetic sensitivity in our general population. Triglycerides deposited in the liver cells are required for the ontogenesis of NAFLD. The reason in favor of this metabolic proceeding to deposition of lipids in the liver cells remains tacit, but it is suggested that this could be due to the resistance of insulin alters the pathway of consumption, formation, degradation and are releasing of the substances in liver metabolism. The basic mechanism of consequences resulting in lipid accumulation are not understand, but alteration in the pathway related with uptake, formation, deprivation, or oozing of substances in metabolism in liver result due to resistance for insulin are assumed. Resistance for Insulin is the common agent leading to ontogenesis of NAFLD [21].

In these subjects, significant variations had observed in fasting lipid profile. Increased serum triglycerides observed in fatty liver (non-alcoholic disease) pa- 
tients in a research conducted in USA by Clark [22]. Also another study had shown increased serum triglycerides in these (NAFLD) subjects conducted in Brazil [23].

Research conducted in Maxico by Lizar-di-Cervera et al. [24] analyzed that $63 \%$ of fatty liver (non-alcoholic disease) subjects had higher cholesterol levels. The findings of current study were compareable with other studies and shown that there were remarkable alterations in the lipid profile with different grades of fatty liver, the cholesterol value was abnormal in 186 (62\%), while normal in remaining 114 (38\%) patients. Triglycerides were abnormal in 152 (50.7\%) while in $148(49.3 \%)$ patients was normal. HDL in 155 (51.7\%) patients was abnormal while $145(48.3 \%)$ patients had normal values. Low density lipoprotein value in 117 (39\%) patient was abnormal and 183 (61\%) patient normal. Very low-density lipoprotein in 117 (39\%) patients was abnormal and 183 (61\%) patient normal. Total serum cholesterol and serum triglyceride levels increased in fatty liver (non-alcoholic disease) patients as compared with controls [25]. Another study by Bajaj et al. [26] in fatty liver (non-alcoholic disease) patients shown increased total serum cholesterol and triglycerides levels. Present study results are comparable at global level.

Ultrasonic findings along with considerably raised fasting lipid profile are the safe, cheap, easy, and accurate available diagnostic tool for fatty liver (non-alcoholic disease) [11]. Ultrasound (USG) foremost imaging technique used to establish and categorize the fatty liver disease and extensively used for the suspects of NAFLD and also asymptomatic subjects having raised hepatic enzymes.

In current study, ultrasound provided excellent utility for diagnosis of fatty liver (NAFLD) by means of raised levels of fasting lipid profile. This is detected earlier by ultrasonography. There is statically significant relation in subjects diagnosed on ultrasound and serum fasting profile of lipid of fatty liver (non-alcoholic disease). Ultrasound is cost effective technique to analyze the changes seen in various grades of NAFLD. Ultrasonography also decreases needless contact, costly, complex and tiresome investigations in these subjects as well as in asymptomatic patients.

There were $176(58.7 \%)$ patients in grade I, while $82(27.3 \%)$ patients in grade II and $42(14 \%)$ patients in grade III.

The cholesterol value was abnormal in 186 (62\%), while normal in remaining $114(38 \%)$ patients. Triglycerides were abnormal in 152 (50.7\%) while in 148 (49.3\%) patients was normal. HDL in 155 (51.7\%) patients was abnormal while $145(48.3 \%)$ patients had normal values. Low density lipoprotein value in 117 (39\%) patient was abnormal and 183 (61\%) patient normal. Very low-density lipoprotein in 117 (39\%) patients was abnormal and 183 (61\%) patient normal. Santoshini A et al. [13] in their research found that lipid profile was greatly altered in NAFLD with Grade I, II and III (48.48\%, 38.79\% and 12.73\%) respectively. In present study there was statistically significant correlation of triglycerides with grades of fatty liver ( $p$ value 0.012 ), age ( $p$ value 0.030 ), cholesterol ( $p$ 
value 0.000 ), LDL-C (p value 0.000 ) and VLDL-C ( $\mathrm{p}$ value 0.000 ). The correlation amongst grades of fatty liver was statistically significant with TG-C ( $p$-value 0.012 ) and no significant relation with other variables of lipid profile and age. This study has shown that subjects diagnosed as having fatty liver on ultrasound, their fasting lipid profile remains deranged. Subjects diagnosed on ultrasonographically had shown statically a substantial relationship with fasting lipid profile ( $\mathrm{p}$ value $<0.05$ ). Current study established that ultrasonography is the most cost effective technique to analyze the changes seen in various NAFLD grades. Ultrasonography also decreases needless contact, costly, complex and tiresome investigations in these subjects as well as in asymptomatic patients. Ultrasound (USG) is the foremost imaging technique used to establish and categorize changes related to fatty liver (non-alcoholic disease). Ultrasound is the cost effective technique to analyze the changes seen in various grades of NAFLD. Ultrasonography also decreases needless contact, costly, complex and tiresome investigation in these subjects as well as in asymptomatic patients. So this study recommends that fatty liver (NAFLD) can be detected earlier by ultrasonography.

\section{Conclusion}

Early detection and precautionary measurements should be taken to understand the pattern of the disease. Time tested decision for the treatment of disease should be carried out immediately to control the possible unwanted outcome of the NAFLD in terms of disability and death.

\section{Financial Support and Sponsorship}

No funding from any institute or organization.

\section{Conflict of Interest}

Author declares no conflict of interest.

\section{References}

[1] Ludwig, J., Viggiano, T.R., McGill, D.B. and Oh, B.J. (1980) Nonalcoholic Steatohepatitis Mayo Clinic Experiences with a Hitherto Unnamed Disease. Mayo Clinic Proceedings, 55, 434-438.

[2] Mahaling, D.U. and Basavaraj, M.M. (2013) Comparison of Lipid Profile in Different Grades of Non-Alcoholic Fatty Liver Disease Diagnosed on Ultrasound. Asian Pacific Journal of Tropical Biomedicine, 3, 907-912. https://doi.org/10.1016/S2221-1691(13)60177-X

[3] Angulo, P. (2002) Nonalcoholic Fatty Liver Disease. The New England Journal of Medicine, 346, 1221-1231. https://doi.org/10.1056/NEJMra011775

[4] Pandey, G. and Balakrishnan, V. (2009) Clinico-Pathological Spectrum of Non-Alcoholic Fatty Liver Disease among Patients in Kerala. Indian Journal of Clinical Biochemistry, 24, 155-158. https://doi.org/10.1007/s12291-009-0028-8

[5] David, A.S., Chang, P. and Chopra, K. (2005) Non-Alcoholic Fatty Liver Disease: 
Clinical Review. Digestive Diseases and Sciences, 50, 171-180.

https://doi.org/10.1007/s10620-005-1267-Z

[6] Sen, A., Kumar, J., Misra, R.P., Uddin, M. and Shukla, P.C. (2013) Lipid Profile of Patients Having Non-Alcoholic Fatty Liver Disease as per Ultrasound Findings in North Indian Population: A Retrospective Observational Study. Journal of Medical and Allied Sciences, 3, 59-62.

[7] Schild, B.Z., Santos, L.N. and Alves, M.K. (2013) Non-Alcoholic Fatty Liver Disease and Its Association with Metabolic Syndrome in the Preoperative Period in Patients Undergoing Bariatric Surgery. Revista da Associa Medica Brasileira, 59, 155-160. https://doi.org/10.1016/j.ramb.2012.10.004

[8] McCullough, A.J. and Hawkins, C. (2015) Clinical Spectrum of Non-Alcoholic Fatty Liver Disease in Diabetic and Non-Diabetic Patients. BBA Clinical, 3, 141-145. https://doi.org/10.1016/j.bbacli.2014.09.001

[9] Obika, M. and Noguchi, H. (2012) Diagnosis and Evaluation of Nonalcoholic Fatty Liver Disease. Experimental Diabetes Research, 2012, 1-12. https://doi.org/10.1155/2012/145754

[10] Sertoglu, E. and Ercin, C.N. (2014) The Relationship of Serum Uric Acid with Non-Alcoholic Fatty Liver Disease. Clinical Biochemistry, 47, 383-388. https://doi.org/10.1016/j.clinbiochem.2014.01.029

[11] Javed, M. (2014) Fatty Liver: Yet another Silent Killer. Journal of Ayub Medical College Abbottabad, 26, 26-30.

[12] Uzma, B., Murtaza, G. and Shaheen, M. (2008) Evaluation of Risk Factors of Non Alcoholic Fatty Liver Disease (NAFLD) in a Tertiary Care Hospital at Rawalpindi, Pakistan: A Local Experience. Journal of Postgraduate Medical Institute, 22, 189-195.

[13] Santoshini, A., Swathi, P. and Ravindra, B. (2016) Estimation of Lipid Profile in Various Grades of Non Alcoholic Fatty Liver Disease Diagnosed on Ultrasonography. International Journal of Pharma and Bio Sciences, 7, 1198-1203.

[14] Holterman, A. and Somma, N.D. (2014) Nonalcoholic Fatty Liver Disease and Bariatric Surgery in Adolescents. Seminars in Pediatric Surgery, 23, 49-57. https://doi.org/10.1053/j.sempedsurg.2013.10.016

[15] Chalasani, N., Younossi, Z., Lavine, J.E., Diehl, A.M., Brunt, E.M., Cusi, K., et al. (2012) The Diagnosis and Management of Non-Alcoholic Fatty Liver Disease: Practice Guideline by the American Association for the Study of Liver Diseases, American College of Gastroenterology, and the American Gastroenterological Association. Hepatology, 55, 2005-2023. https://doi.org/10.1002/hep.25762

[16] Machado, M.V. and Cortez-Pinto, H. (2007) Noninvasive Diagnosis of Non-Alcoholic Fatty Liver Disease a Critical Appraisal. Journal of Hepatology, 49, 156-162.

[17] Donnelly, K.L., Smith, C.I., Schwarzenberg, S.J., Jessurun, J., Boldt, M.D. and Parks, E.J. (2005) Sources of Fatty Acids Stored in Liver and Secreted via Lipoproteins in Patients with Nonalcoholic Fatty Liver Disease. Journal of Clinical Investigation, 115, 1343-1351. https://doi.org/10.1172/JCI23621

[18] Lazo, M., Hernaez, R., Eberhardt, M.S., Bonekamp, S., Kamel, I., Guallar, E., Koteish, A., et al. (2013) Prevalence of Nonalcoholic Fatty Liver Disease in the United States: The Third National Health and Nutrition Examination Survey, 1988-1994. American Journal of Epidemiology, 178, 38-45. https://doi.org/10.1093/aje/kws448

[19] Agrawal, R., Mishra, S., Dixit, V.K. and Rai, S. (2009) Association of Non-Alcoholic Fatty Liver Disorder with Obesity. Indian Journal of Preventive and Social Medi- 
cine, 40, 126-129.

[20] Amarapurkar, D.N. and Amarapurkar, A.D. (2000) Nonalocholic Steatohepatitis: Clinicopathologic Profile. Journal of the Association of Physicians of India, 48, 311-313.

[21] Clark, J.M. (2006) The Epidemiology of Nonalcoholic Fatty Liver Disease in Adults. Journal of Clinical Gastroenterology, 40, 5-10.

[22] Leite, N.C., Salles, G.F., Araujo, A.L., et al. (2009) Prevalence and Associated Factors of Non-Alcoholic Fatty Liver Disease in Patients with Type-2 Diabetes Mellitus. Liver International, 29, 113-119. https://doi.org/10.1111/j.1478-3231.2008.01718.x

[23] Lizardi-Cervera, J., Laparra, D.I., Chávez-Tapia, N.C., et al. (2006) Prevalence of NAFLD and Metabolic Syndrome in Asym-Tomatics Subjects. Revista de Gastroenterología de México, 71, 453-459.

[24] Sathiaraj, E., Chutke, M., Reddy, M.Y., et al. (2011) A Case-Control Study on Nutritional Risk Factors in Non-Alcoholic Fatty Liver Disease in Indian Population. $E u$ ropean Journal of Clinical Nutrition, 65, 533-537. https://doi.org/10.1038/ejcn.2011.3

[25] Bajaj, S., Nigam, P. and Luthra, A. (2009) A Case-Control Study on Insulin Resistance, Metabolic Co-Variates \& Prediction Score in Non-Alcoholic Fatty Liver Disease. Indian Journal of Medical Research, 129, 285-292.

[26] El-Koofy, N.M., Anwar, G.M. and EI-Raziky, M.S. (2012) The Association of Metabolic Syndrome, Insulin Resistance and Non-Alcoholic Fatty Liver Disease in Overweight/Obese Children. Saudi Journal of Gastroenterology, 18, 44-49. https://doi.org/10.4103/1319-3767.91738 